\title{
Mutation analysis of the $M E C P 2$ gene in patients of Slavic origin with Rett syndrome: novel mutations and polymorphisms
}

\author{
Daniela Zahorakova $\cdot$ Robert Rosipal · Jan Hadac $\cdot$ \\ Alena Zumrova · Vladimir Bzduch · Nadezda Misovicova • \\ Alice Baxova · Jiri Zeman · Pavel Martasek
}

Received: 4 December 2006/ Accepted: 19 January 2007/ Published online: 15 February 2007

(C) The Japan Society of Human Genetics and Springer 2007

\begin{abstract}
Rett syndrome (RTT), an X-linked dominant neurodevelopmental disorder in females, is caused mainly by de novo mutations in the methylCpG-binding protein 2 gene $(M E C P 2)$. Here we report mutation analysis of the $M E C P 2$ gene in 87 patients with RTT from the Czech and Slovak Republics, and Ukraine. The patients, all girls, with classical RTT were investigated for mutations using bi-directional DNA sequencing and conformation sensitive gel
\end{abstract}

Electronic supplementary material The online version of this article (doi:10.1007/s10038-007-0121-x) contains supplementary material, which is available to authorized users.

D. Zahorakova $\cdot$ R. Rosipal $\cdot$ J. Zeman .

P. Martasek $(\triangle)$

Department of Pediatrics, First School of Medicine,

Charles University, Ke Karlovu 2, 12808

Prague 2, Czech Republic

e-mail: pavel.martasek@gmail.com

J. Hadac

Department of Child Neurology,

Thomayer University Hospital, Prague, Czech Republic

\section{A. Zumrova}

Department of Child Neurology, University Hospital Motol,

Prague, Czech Republic

\section{Bzduch}

First Department of Pediatrics, Commenius University

Children's Hospital, Bratislava, Slovakia

\section{N. Misovicova}

Department of Clinical Genetics,

Martin University Hospital, Martin, Slovakia

\section{A. Baxova}

Institute of Biology and Clinical Genetics,

General University Hospital, Prague, Czech Republic electrophoresis analysis of the coding sequence and exon/intron boundaries of the MECP2 gene. Restriction fragment length polymorphism analysis was performed to confirm the mutations that cause the creation or abolition of the restriction site. Mutationnegative cases were subsequently examined by multiple ligation-dependent probe amplification (MLPA) to identify large deletions. Mutation screening revealed 31 different mutations in 68 patients and 12 nonpathogenic polymorphisms. Six mutations have not been previously published: two point mutations (323T $>A$ A, 904C $>$ T), three deletions (189_190delGA, 816_832del17, 1069delAGC) and one deletion/inversion (1063_1236del174;1189_1231inv43). MLPA analysis revealed large deletions in two patients. The detection rate was $78.16 \%$. Our results confirm the high frequency of $M E C P 2$ mutations in females with RTT and provide data concerning the mutation heterogeneity in the Slavic population.

Keywords Rett syndrome - Mental retardation . MECP2 gene $\cdot$ Mutation screening - MLPA

\section{Introduction}

Rett syndrome (RTT; OMIM 312750), first described by the Austrian pediatrician Rett (1966), is one of the leading causes of mental retardation and developmental regression in girls. Its prevalence is estimated to be from 1:10,000 to 1:15,000 females worldwide with most cases being sporadic (Hagberg 1995). Patients with classical RTT show an apparently normal psychomotor development during the first 6-18 months of life. Thereafter, they enter a short period of developmental 
stagnation followed by a rapid regression in language and motor development. Purposeful hand use is often lost and replaced by repetitive, stereotypic movements. Additional symptoms include acquired microcephaly, gait ataxia/apraxia, seizures, and episodic apnea and/or hyperpnea (Hagberg et al. 1983; Naidu 1997). The causative gene was mapped to $\mathrm{Xq} 28$ and identified as the MECP2 gene (Amir et al. 1999). It encodes the methyl-CpG-binding protein 2 (MeCP2; OMIM 300005), which is involved in regulation oftranscription repression, epigenetic gene silencing (Amir et al. 1999; Van den Veyver and Zoghbi 2000), and RNA splicing (Young et al. 2004). Several different MECP2 mutations have been identified in up to $90 \%$ of classical RTT patients worldwide. The mutation rate in atypical cases is much lower: $20-40 \%$ (Hoffbuhr et al. 2002; Laccone et al. 2004; Amir et al. 2005). We present a mutation analysis of the MECP2 gene in RTT patients from the Czech Republic, Slovakia, and Ukraine. We tested 87 patients with classical RTT to ascertain the spectrum of disease-causing mutations of $M E C P 2$ gene in the Slavic population.

\section{Subjects and methods}

\section{Patients}

Most of 87 unrelated sporadic female patients with a clinical diagnosis of RTT were diagnosed in neurological, genetic, or pediatric departments. Several patients were identified from Institutes of social work for mentally retarded children. All patients included in this study were diagnosed as having classical RTT, with psychomotor regression after a period of normal development, severe mental retardation, postnatal deceleration of head growth, loss of speech and purposeful hand use, and the appearance of stereotypic hand movements. The diagnosis was made according to diagnostic criteria defined by the Rett syndrome diagnostic criteria work group (Kerr et al. 2001).

\section{Molecular analyses}

Genomic DNA was extracted from peripheral blood samples anticoagulated with EDTA according to a standard protocol. Coding sequences of exons 1, 2, 3, and 4 with flanking exon/intron boundaries were amplified using following primer pairs: $1 \mathrm{FW} 5^{\prime}$-tcaatc gcccctcagagca-3', 1Rev 5'-cacgtcccgcccctgaccc-3'; $2 \mathrm{Fw}$ $5^{\prime}$-aaaaaggtcgtgcagctcaa-3'，2Rev 5'-ggccaaaccaggaca tatac-3'; 3Fw 5'-tggcatgttctctgtgatactt-3', 3Rev 5'-cctggg cacatacattttcct-3'; $4 \mathrm{aFw} \quad 5^{\prime}$-tttgtcagagcgttgtcacc-3', $4 \mathrm{aRev} 5^{\prime}$-ctgcacagatcggatagaagac-3'; 4bFw 5'-ggcaggaa gcgaaaagctgag- $3^{\prime}, 4 \mathrm{bRev} 5^{\prime}$-ctccctcccctcggtgtttg- $3^{\prime}, 4 \mathrm{cFw}$ $5^{\prime}$-ggagaagatgcccagaggag- $3^{\prime}, 4 \mathrm{cRev} \quad 5^{\prime}$-gcactgatggcacc gaaaac- $3^{\prime}$. The PCR amplification of exon 1 was carried out as published elsewhere (Evans et al. 2005), exons 2, 3 , and 4 were amplified in a total volume of $25 \mu \mathrm{l}$ including 1x Plain PP Master Mix $[150 \mathrm{mM}$ Tris- $\mathrm{HCl}$, $\mathrm{pH} 8.8,40 \mathrm{mM}\left(\mathrm{NH}_{4}\right)_{2} \mathrm{SO}_{4}, 0.02 \%$ Tween $20,5 \mathrm{mM}$ $\mathrm{MgCl}_{2}, 400 \mu \mathrm{M}$ dATP, $400 \mu \mathrm{M}$ dCTP, $400 \mu \mathrm{M}$ dGTP, $400 \mu \mathrm{M}$ dTTP, $100 \mathrm{U} / \mathrm{ml}$ Taq DNA polymerase; TopBio, Prague, Czech Republic] and $0.4 \mathrm{mM}$ of each primer. Thermal cycling conditions included an initial denaturation at $94^{\circ} \mathrm{C}$ for 2 min followed by 33 cycles of denaturation at $94^{\circ} \mathrm{C}$ for $30 \mathrm{~s}$, annealing at $63^{\circ} \mathrm{C}$ for $30 \mathrm{~s}$, and elongation at $72^{\circ} \mathrm{C}$ for $45 \mathrm{~s}$, followed by final extension at $72^{\circ} \mathrm{C}$ for $10 \mathrm{~min}$.

PCR products were purified from agarose gels using a QIAquick gel extraction kit (Qiagen, Hilden, Germany). Exon 2 was analysed by conformation sensitive gel electrophoresis (CSGE) as described (Bourdon et al. 2001). Exons 1, 3, and 4 were sequenced in both directions on automatic sequencer ABI PRISM 3100/ 3100-Avant Genetic analyzer (Applied Biosystems, Foster City, CA) using the ABI PRISM BigDye terminator v3.1 (Applied Biosystems). Whenever the identified mutation caused creation or loss of a restriction site, it was confirmed by restriction fragment length polymorphism (RFLP) analysis. To confirm del/ inv mutations, the PCR fragment with the mutation was cloned into pCR4-TOPO vector (TOPO TA Cloning Kit for Sequencing, Invitrogen, Carlsbad, CA). Plasmid DNA was amplified in Top10 chemically competent Escherichia coli cells (Invitrogen), isolated using the QIAprep Spin Miniprep Kit (Qiagen), and sequenced. We used probe mix P015 (MRC Holland, Amsterdam, The Netherlands) for MLPA in all mutation-negative patients. MLPA was performed according to manufacturer's protocol (see Supplementary material). Genotyping was performed on an ABI PRISM 3100/3100-Avant Genetic analyzer (Applied Biosystems). Aberrant results were independently re-run in the second MLPA reaction for confirmation.

\section{Ethics}

The study was carried out in accordance with the Declaration of Helsinki of the World Medical Association and was approved by the Committee of Medical Ethics at the University Hospital. Informed consent was obtained from parents of all patients. 


\section{Results}

The molecular analysis revealed 31 different mutations in 68 patients $(78.16 \%)$, which is consistent with estimates reported elsewhere. Of the 68 patients with mutations, 34 had a missense mutation, 18 had a nonsense mutation, 13 carried a frame-shift mutation, 1 had an in frame deletion, and 2 had large-scale deletions detected by MLPA (Table 1). Three mutations were located in exon 3 , the rest in exon 4 . No sequence change was identified in exons 1 and 2 . We identified six novel mutations (Fig. 1): two point mutations (323T $>$ A, 904C $>$ T), three deletions (189_190delGA, 816_832del17, 1069delAGC), and one deletion/inversion (1063_1236del174;1189_1231inv43).
We screened the parents and sisters of our patients for the mutations found in their daughters and sisters if their blood samples were available, but found none. The mutations were thus either de novo or due to germ-line mosaicism in the parents. Further sequencing analysis did not reveal any of newly described mutations in 200 normal chromosomes tested. Twelve non-pathogenic polymorphisms were identified in 14 patients, 4 of which are novel (Table 2).

\section{Discussion}

$M E C P 2$ is an $\mathrm{X}$-linked gene encoding two almost identical isoforms of MeCP2 with alternative $\mathrm{N}$-termini

Table 1 Mutations in the methyl-CpG-binding protein 2 gene (MECP2) detected in reported patients with Rett syndrome (RTT). $M B D$ Methyl-CpG-binding domain, TRD transcription repression domain, $C$-ter C-terminal region, $M L P A$ multiple ligation-dependent probe amplification

\begin{tabular}{|c|c|c|c|c|c|}
\hline Exon & Nucleotide change $^{\mathrm{a}}$ & $\begin{array}{l}\text { Amino acid } \\
\text { change }\end{array}$ & $\begin{array}{l}\text { Domain } \\
\text { of MeCP2 }\end{array}$ & $\begin{array}{l}\text { Recurrence } \\
\text { (this study) }\end{array}$ & Reference \\
\hline 3 & 189_190delGA & E63fsX27 & - & 1 & This study \\
\hline 3 & $316 \mathrm{C}>\mathrm{T}$ & R106W & MBD & $5\left(4^{b}\right)$ & Amir et al. 1999 \\
\hline 3 & $323 \mathrm{~T}>\mathrm{A}$ & L108H & MBD & 1 & This study \\
\hline 4 & $397 \mathrm{C}>\mathrm{T}$ & $\mathrm{R} 133 \mathrm{C}$ & MBD & $6\left(1^{b}\right)$ & Amir et al. 1999 \\
\hline 4 & $401 \mathrm{C}>\mathrm{G}$ & $\mathrm{S} 134 \mathrm{C}$ & MBD & 1 & Cheadle et al. 2000 \\
\hline 4 & $403 \mathrm{~A}>\mathrm{G}$ & $\mathrm{K} 135 \mathrm{E}$ & MBD & 1 & Laccone et al. 2001 \\
\hline 4 & $423 \mathrm{C}>\mathrm{G}$ & Y141X & MBD & $1\left(1^{\mathrm{b}}, 1^{\mathrm{c}}\right)$ & De Bona et al. 2000 \\
\hline 4 & $430 \mathrm{~A}>\mathrm{T}$ & K144X & MBD & 1 & Buyse et al. 2000 \\
\hline 4 & $455 \mathrm{C}>\mathrm{G}$ & P152R & MBD & 1 & Cheadle et al. 2000 \\
\hline 4 & $473 \mathrm{C}>\mathrm{T}$ & $\mathrm{T} 158 \mathrm{M}$ & MBD & $11\left(10^{\mathrm{b}}, 1^{\mathrm{c}}\right)$ & Amir et al. 1999 \\
\hline 4 & $502 \mathrm{C}>\mathrm{T}$ & R168X & - & $3\left(4^{\mathrm{b}}, 1^{\mathrm{c}}\right)$ & Wan et al. 1999 \\
\hline 4 & $611 \mathrm{C}>\mathrm{G}$ & S204X & - & $1\left(1^{\mathrm{b}}, 1^{\mathrm{c}}\right)$ & Buyse et al. 2000 \\
\hline 4 & $674 \mathrm{C}>\mathrm{G}$ & $\mathrm{P} 225 \mathrm{R}$ & TRD & $1\left(1^{\mathrm{c}}\right)$ & Cheadle et al. 2000 \\
\hline 4 & 750_751insC & G252fsX7 & TRD & 1 & Zeev et al. 2002 \\
\hline 4 & $763 \bar{C}>\mathrm{T}$ & $\mathrm{R} 255 \mathrm{X}$ & TRD & 5 & Amir et al. 1999 \\
\hline 4 & 806delG & G269fsX20 & TRD & 2 & Wan et al. 1999 \\
\hline 4 & $808 \mathrm{C}>\mathrm{T}$ & $\mathrm{R} 270 \mathrm{X}$ & TRD & $3\left(1^{b}\right)$ & Cheadle et al. 2000 \\
\hline 4 & 816_832del17 & G273fsX52 & TRD & 1 & This study \\
\hline 4 & 856_859del4 & K286fsX2 & TRD & 1 & Hoffbuhr et al. 2001 \\
\hline 4 & $880 \overline{\mathrm{C}}>\mathrm{T}$ & $\mathrm{R} 294 \mathrm{X}$ & TRD & $4\left(1^{\mathrm{b}}, 1^{\mathrm{c}}\right)$ & Cheadle et al. 2000 \\
\hline 4 & $904 \mathrm{C}>\mathrm{T}$ & P302S & TRD & 1 & This study \\
\hline 4 & $916 \mathrm{C}>\mathrm{T}$ & $\mathrm{R} 306 \mathrm{C}$ & TRD & $5\left(2^{\mathrm{b}}, 1^{\mathrm{c}}\right)$ & Wan et al. 1999 \\
\hline 4 & 1063_1236del174;1189_1231inv43 & S355fsX37 & C-ter & $1\left(1^{\mathrm{b}}, 1^{\mathrm{c}}\right)$ & This study \\
\hline 4 & $1069 \mathrm{delAGC}$ & $\Delta \mathrm{S} 357$ & C-ter & $1\left(1^{\mathrm{b}}\right)$ & This study \\
\hline 4 & 1116_1201del86 & $\mathrm{H} 372 \mathrm{fs} X 4$ & C-ter & $1\left(1^{b}\right)$ & Amir and Zoghbi 2000 \\
\hline 4 & 1157_1197del41 & L386fsX5 & C-ter & $1\left(1^{b}\right)$ & Cheadle et al. 2000 \\
\hline 4 & 1157_1200del44 & L386fsX4 & C-ter & 1 & Huppke et al. 2000 \\
\hline 4 & $1162 \bar{C}>\mathrm{T}$ & P388S & C-ter & 1 & Conforti et al. 2003 \\
\hline 4 & 1164_1207del44 & P389fsX1 & C-ter & $3\left(1^{\mathrm{b}}, 1^{\mathrm{c}}\right)$ & Buyse et al. 2000 \\
\hline \multicolumn{6}{|c|}{ Large deletions identified by MLPA } \\
\hline 3,4 & Deletion of exon 3 and a part of exon 4 & & & 1 & This study \\
\hline 4 & Deletion of exon 4 near stop codon & & & 1 & This study \\
\hline
\end{tabular}

${ }^{a}$ Numbered according to GenBank NM_004992

b Number of parents tested for the $M E C P 2$ mutation identified in proband

${ }^{c}$ Number of sisters tested for the $M E C P 2$ mutation identified in proband 
Fig. 1a-e Novel mutations in the methyl-CpG-binding protein 2 gene $(M E C P 2)$ in sporadic Rett syndrome (RTT) patients. a-e Top patient, bottom healthy control. f Region containing del/inv mutation cloned into pCR4-TOPO vector. Each allele was sequenced separately. Top Allele with mutation (arrow indicates the first mutated base), bottom normal allele

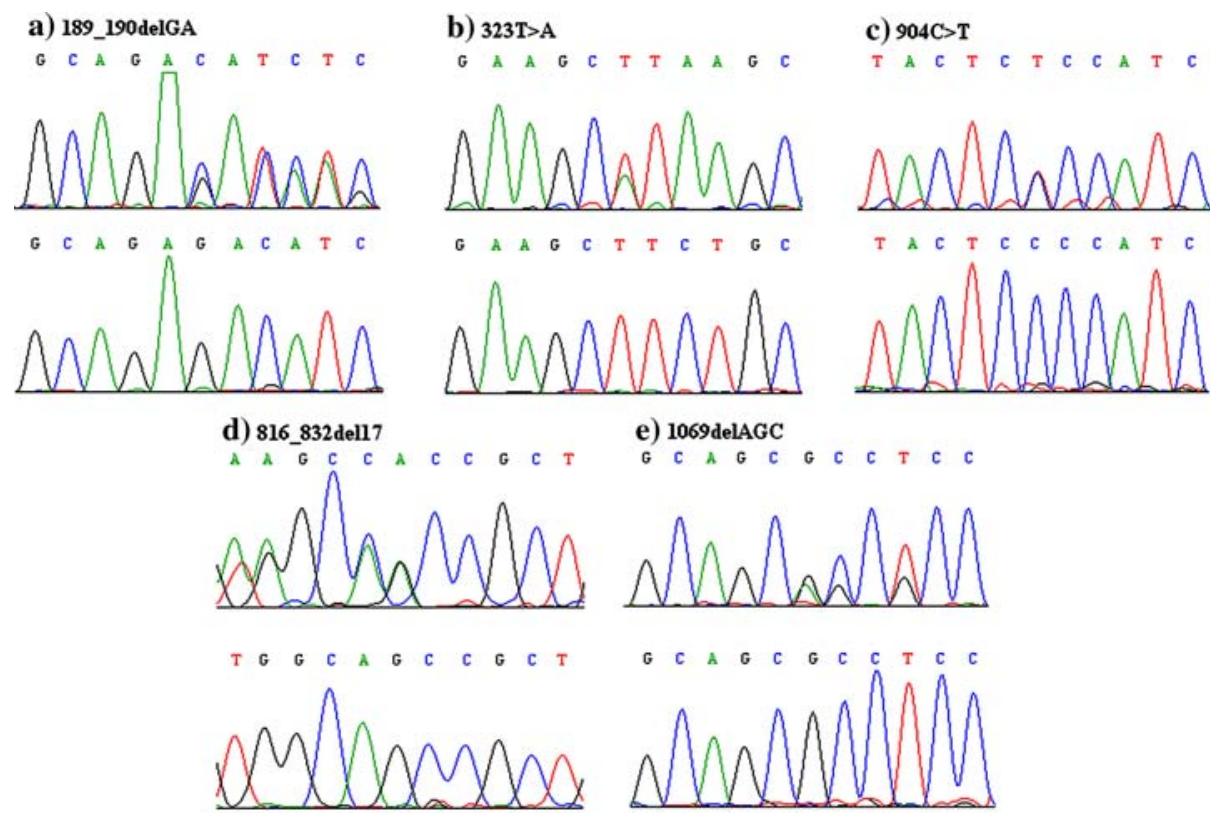

f) 1063_1236dell74;1189_123linv43

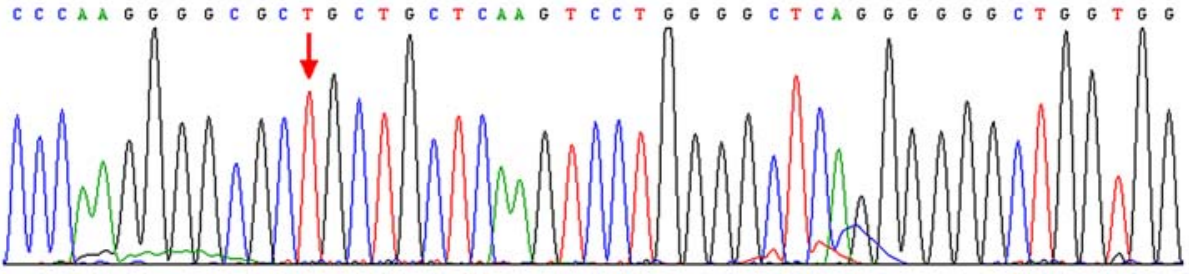

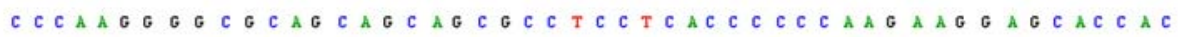



Table 2 Non-pathogenic polymorphisms in the MECP2 gene detected in reported patients with RTT

\begin{tabular}{|c|c|c|c|c|c|c|}
\hline Exon/intron & $\begin{array}{l}\text { Nucleotide } \\
\text { change }\end{array}$ & $\begin{array}{l}\text { Amino acid } \\
\text { change }\end{array}$ & $\begin{array}{l}\text { Domain } \\
\text { of } \mathrm{MeCP} 2\end{array}$ & $\begin{array}{l}\text { Recurrence } \\
\text { (this study) }\end{array}$ & $\begin{array}{l}\text { Parental } \\
\text { origin }\end{array}$ & Reference \\
\hline Intron 3 & $\mathrm{IVS} 3+22 \mathrm{C}>\mathrm{G}$ & - & - & 2 & $\mathrm{NA}^{\mathrm{a}}$ & Couvert et al. 2001 \\
\hline Intron 3 & IVS3-17delT & - & - & 1 & Paternal $^{\mathrm{b}}$ & Erlandson et al. 2001 \\
\hline Exon 4 & $587 \mathrm{C}>\mathrm{G}$ & T196S & - & 1 & Paternal & Shibayama et al. 2004 \\
\hline Exon 4 & $686 \mathrm{C}>\mathrm{T}$ & S229L & TRD & 1 & NA & Cheadle et al. 2000 \\
\hline Exon 4 & $815 \mathrm{C}>\mathrm{T}$ & $\mathrm{P} 272 \mathrm{~L}$ & TRD & 1 & Paternal & RettBASE $^{c}$ \\
\hline Exon 4 & $819 \mathrm{G}>\mathrm{T}$ & G273G & TRD & 1 & NA & RettBASE $^{c}$ \\
\hline Exon 4 & $1161 \mathrm{C}>\mathrm{T}$ & P387P & C-ter & 1 & NA & RettBASE $^{c}$ \\
\hline Exon 4 & $1335 \mathrm{G}>\mathrm{A}$ & $\mathrm{T} 445 \mathrm{~T}$ & C-ter & 1 & NA & RettBASE $^{c}$ \\
\hline Exon 4 & $1553 \mathrm{C}>\mathrm{T}$ & - & 3'UTR & 1 & NA & This study \\
\hline Exon 4 & $1789 \mathrm{G}>\mathrm{A}$ & - & 3'UTR & 2 & Paternal (both) & This study \\
\hline Exon 4 & $1820 \mathrm{G}>\mathrm{C}$ & - & 3'UTR & 1 & NA & This study \\
\hline Exon 4 & $1824 \mathrm{G}>\mathrm{C}$ & - & 3'UTR & 1 & NA & This study \\
\hline
\end{tabular}

\footnotetext{
${ }^{a}$ DNA from parents not available

b Polymorphism identified also in father's mother

c RettBASE: http://www.mecp2.chw.edu.au/
} 
(Mnatzakanian et al. 2004). The MeCP2 protein has two major functional domains: the methyl-CpG-binding domain (MBD), which binds specifically to DNA methylated at $\mathrm{CpGs}$; and the transcription repression domain (TRD), which mediates transcription repression through the recruitment of other proteins (Jones et al. 1998; Nan et al. 1998).

In this paper, we report the mutational analysis of the whole coding sequence of the MECP2 gene. Altogether, we identified a heterogeneous spectrum of mutations, including several novel MECP2 mutations and polymorphisms, in a high proportion $(78.16 \%)$ of classical RTT patients. The transversion $323 \mathrm{~T}>\mathrm{A}$ in exon 3 leads to a substitution of a highly conserved lysine to histidine at position 108. The mutation is localized within the MBD and may affect methylationspecific binding of the protein to the DNA template. Missense mutations in the MBD most likely disrupt the integrity of the domain or interfere with MeCP2's ability to bind methylated DNA. The $904 \mathrm{C}>\mathrm{T}$ transition causes the substitution of proline with serine at position 302, which lies within the TRD. This sequence change probably alters the ability of the protein to recruit co-repressor complexes and affects its function in the process of transcription repression. Mutations involving the TRD could interfere with the assembly of the transcriptional silencing complex, abolishing interactions with the $\operatorname{Sin} 3 \mathrm{~A}$ corepressor or histone deacetylase recruitment. Binding of truncated MeCP2 to methylated DNA could also provide steric hindrance to the transcription complex. MBD-containing mutant proteins without TRD might accomplish some degree of silencing, either by recruiting the silencing complex by a TRD-independent mechanism or by directly interfering with binding of transcription factors (Ballestar et al. 2000). The 189_190delGA deletion in exon 3 causes a frame-shift, with threonine at position 63 as the first affected amino acid. The mutation introduces a premature stop codon occurring 27 codons downstream (E63fsX27). Another frameshift mutation due to a 17-bp deletion (816_832del17) creates a stop codon after 51 missense amino acids in the TRD (G273fsX52). Deletion 1069delAGC leads to the removal of one serine without alteration of the coding frame $(\Delta \mathrm{S} 357)$. The deleted serine is a part of the SSSASS motif (deleted S357 underlined), which is conserved between human, rat and mouse. Its function is still not clear. A combined deletion/inversion mutation 1063_1236del;1189_1231inv43 was confirmed by cloning of the affected region of the MECP2 gene into a vector and sequencing of each allele separately. The mutation alters the open reading frame, with codon 355 being the first affected, and leads to the creation of a premature stop codon 37 codons downstream (S355fsX37).

Most of the missense mutations were located in the MBD, while the nonsense mutations were more scattered, located from the end of MBD to the TRD. Deletions were located mostly in the C-terminal region. The eight most common mutations $(316 \mathrm{C}>\mathrm{T}$, $397 \mathrm{C}>\mathrm{T}, 473 \mathrm{C}>\mathrm{T}, 502 \mathrm{C}>\mathrm{T}, 763 \mathrm{C}>\mathrm{T}, 808 \mathrm{C}>\mathrm{T}, 880 \mathrm{C}>\mathrm{T}$, $916 \mathrm{C}>\mathrm{T}$ ), accounting for more than half of all mutations in probands with RTT, were located at CpGs, which would support the hypothesis that these motifs are mutation hot-spots, as suggested by, among others, Wan et al. (1999).

Novel polymorphisms 1553C $>\mathrm{T}, 1789 \mathrm{G}>\mathrm{A}$, $1820 \mathrm{G}>\mathrm{C}$, and $1824 \mathrm{G}>\mathrm{C}$ are localized in the $3^{\prime} \mathrm{UTR}$ and do not affect the protein sequence. Unfortunately, we were not able to obtain DNA samples from the parents of these patients, hence the parental origin of the polymorphisms is unknown.

No pathogenic sequence variant was found in 19 patients, although they may have $M E C P 2$ mutations that our methods could not reveal, e.g., mutations in the promotor region or intronic variations introducing novel splice sites. There have also been suggestions that RTT is a genetically heterogeneous disorder, and that other causative genes might exist. Several recent studies identified mutations in the CDKL5 gene (OMIM 300203) encoding cyclin-dependent kinaselike 5 (formerly known as serine/threonine kinase 9; STK9) in patients with an atypical, early seizure variant of RTT (Tao et al. 2004; Weaving et al. 2004; Mari et al. 2005). CDKL5 is a nuclear protein whose expression in the nervous system overlaps with that of $\mathrm{MeCP} 2$ during neural maturation and synaptogenesis. Both proteins interact in vitro and in vivo but the role of CDKL5 in the pathological mechanisms of RTT is still not clear (Mari et al. 2005). A mutation screen of CDKL5 should be considered in mutation-negative patients with early-seizure variant RTT. Moreover, one case of a Netrin G1 mutation has been shown to be associated with a phenotype strongly overlapping that of RTT (Borg et al. 2005), but the causal link of this mutation with RTT, if any, remains to be established.

With the discovery of mutations in the MECP2 gene, RTT became the first human disorder known to be caused by genetic defects in a component of the epigenetic silencing machinery. It is the first pervasive developmental disorder with a known genetic cause and is a prototype for the genetic, molecular, and neurobiological analysis of neurodevelopmental disorders. This study is the first report to document a mutation analysis of the MECP2 gene in RTT patients of Slavic origin. 
Acknowledgments We are grateful to the patients and their families for participating in this study. We would like to thank the physicians who referred their patients with RTT to us and provided us with blood samples, workers from the Institutes of social work for mentally retarded children from Vyskov and Ceske Budejovice, and A. Puchmajerova for technical assistance. This work was supported by grants from the Ministry of Health IGA MZ 8355-3 (D.Z, P.M., and J.Z.) and the Grant Agency of the Charles University GAUK 8/04 (D.Z. and P.M).

\section{References}

Amir RE, Zoghbi HY (2000) Rett syndrome: methyl-CpGbinding protein 2 mutations and phenotype-genotype correlations. Am J Med Genet 97:147-152

Amir RE, Van den Veyver IB, Wan M, Tran CQ, Francke U, Zoghbi HY (1999) Rett syndrome is caused by mutations in X-linked MECP2, encoding methyl-CpG-binding protein 2. Nat Genet 23:185-188

Amir RE, Fang P, Yu Z, Glaze DG, Percy AK, Zoghbi HY, Roa BB, Van den Veyver IB (2005) Mutations in exon 1 of MECP2 are a rare cause of Rett syndrome. J Med Genet 42:e15

Ballestar E, Yusufzai TM, Wolffe AP (2000) Effects of Rett syndrome mutations of the methyl-CpG binding domain of the transcriptional repressor $\mathrm{MeCP} 2$ on selectivity for association with methylated DNA. Biochemistry 39:71007106

Borg I, Freude K, Kubart S, Hoffmann K, Menzel C, Laccone F, Firth H, Ferguson-Smith MA, Tommerup N, Ropers HH, Sargan D, Kalscheuer VM (2005) Disruption of Negrin G1 by a balanced chromosome translocation in a girl with Rett syndrome. Eur J Hum Genet 13:921-927

Bourdon V, Philippe Ch, Labrune O, Amsallem D, Arnould C, Jonveaux P (2001) A detailed analysis of the MECP2 gene: prevalence of recurrent mutations and gross DNA rearrangements in Rett syndrome patients. Hum Genet 108:4350

Buyse IM, Fang P, Hoon KT, Amir RE, Zoghbi HY, Roa BB (2000) Diagnostic testing for Rett syndrome by DHPLC and direct sequencing analysis of the $M E C P 2$ gene: identification of several novel mutations and polymorphisms. Am J Hum Genet 67:1428-1436

Cheadle JP, Gill H, Fleming N, Maynard J, Kerr A, Leonard H, Krawczak M, Cooper DN, Lynch S, Thomas N, Hughes H, Hulten M, Ravine D, Sampson JR, Clarke A (2000) Longread sequence analysis of the $M E C P 2$ gene in Rett syndrome patients: correlation of disease severity with mutation type and location. Hum Mol Genet 9:1119-1129

Conforti FL, Mazzei R, Magariello A, Patitucci A, Gabriele AL, Muglia M, Quattrone A, Fiumara A, Barone R, Pavone L, Nistico R, Mangone L (2003) Mutation analysis of the $M E C P 2$ gene in patients with Rett syndrome. Am J Med Genet 117A:184-187

Couvert P, Bienvenu T, Aquaviva C, Poirier K, Moraine C, Gendrot C, Verloes A, Andres C, Le Fevre AC, Souville I, Steffann J, des Portes V, Ropers HH, Yntema HG, Fryns JP, Briault S, Chelly J, Cherif B (2001) MECP2 is highly mutated in X-linked mental retardation. Hum Mol Genet 10:941-946

De Bona C, Zappella M, Hayek G, Meloni I, Vitelli F, Bruttini M, Cusano R, Loffredo P, Longo I, Renieri A (2000) Preserved speech variant is allelic of classic Rett syndrome. Eur J Hum Genet 8:325-330
Erlandson A, Hallberg B, Hagberg B, Wahlstron J, Martinsson T (2001) MECP2 mutation screening in Swedish classical Rett syndrome females. Eur Child Adolesc Psychiatry 10:117-121

Evans JC, Archer H, Whatley SD, Kerr A, Clarke A, Butler R (2005) Variation in exon 1 coding region and promoter of MECP2 in Rett syndrome and controls. Eur J Hum Genet 13:124-126

Hagberg B (1995) Clinical delineation of Rett syndrome variants. Neuropediatrics 26:62

Hagberg B, Aicardi J, Dias K, Ramos O (1983) A progressive syndrome of autism, dementia, ataxia, and loss of purposeful hand use in girls: Rett's syndrome: report of 35 cases. Ann Neurol 14:471-479

Hoffbuhr K, Devaney JM, LaFleur B, Sirianni N, Scacheri C, Giron J, Schuette J, Innis J, Marino M, Philippart M, Narayanan V, Umansky R, Kronn D, Hoffman EP, Naidu S (2001) MeCP2 mutations in children with and without the phenotype of Rett syndrome. Neurology 56:1486-1495

Hoffbuhr KC, Moses LM, Jerdonek MA, Naidu S, Hoffman EP (2002) Associations between MECP2 mutations, X-chromosome inactivation, and phenotype. Ment Retard Dev Disabil Res Rev 8:99-105

Huppke P, Laccone F, Kramer N, Engel W, Hanefeld F (2000) Rett syndrome: analysis of MECP2 and clinical characterization of 31 patients. Hum Mol Genet 9:1369-1375

Jones PL, Veenstra GJ, Wade PA, Wade PA, Vermaak D, Kass SU, Landsberger N, Strouboulis J, Wolffe AP (1998) Methylated DNA and MeCP2 recruit histone deacetylase to repress transcription. Nat Genet 19:187-191

Kerr AM, Nomura Y, Armstrong D, Anvret M, Belischenko PV, Budden S, Cass H, Christodoulou J, Clarke A, Ellaway C, d'Esposito M, Francke U, Hulten M, Julu P, Leonard H, Naidu S, Schanen C, Webb T, Engerstrom IW, Yamashita Y, Segawa M (2001) Guidelines for reporting clinical features in cases with MECP2 mutations. Brain Dev 23:208-211

Laccone F, Huppke P, Hanefeld F, Meins M (2001) Mutation spectrum in patients with Rett syndrome in the German population: evidence of hot spot regions. Hum Mutat 17:183-190

Laccone F, Junemann I, Whatley S, Morgan R, Butler R, Huppke P, Ravine D (2004) Large deletions of the MECP2 gene detected by gene dosage analysis in patients with Rett syndrome. Hum Mutat 23:234-244

Mari F, Azimonti S, Bertani I, Bolognese F, Colombo E, Caselli R, Scala E, Longo I, Grosso S, Pescucci C, Ariani F, Hayek G, Balestri P, Bergo A, Badaracco G, Zapella M, Broccoli V, Renieri A, Kilstrup-Nielsen C, Landsberger N (2005) CDKL5 belongs to the same molecular pathway of MeCP2 and it is responsible for the early-onset seizure variant of Rett syndrome. Hum Mol Genet 14:1935-1946

Mnatzakanian GN, Lohi H, Munteanu I, Alfred SE, Yamada T, MacLeod PJ, Jones JR, Scherer SW, Schanen NC, Friez MJ, Vincent JB, Minassian BA (2004) A previously unidentified $\mathrm{MECP} 2$ open reading frame defines a new protein isoform relevant to Rett syndrome. Nat Genet 36:339-341

Naidu S (1997) Rett syndrome: natural history and underlying disease mechanisms. Eur Child Adolesc Psychiatry 6(Suppl 1):14-17

Nan X, Ng HH, Johnson CA, Laherty CD, Turner BM, Eisenman RN, Bird A (1998) Transcriptional repression by the methyl-CpG-binding protein $\mathrm{MeCP} 2$ involves a histone deacetylase complex. Nature 393:386-389

Rett A (1966) Über ein eigenartiges hirnatrophisches Syndrom bei Hyperammonemie im Kindesalter. Wien Med Wochenschr 116:723-738 
Shibayama A, Cook EH, Feng J, Glanzmann C, Yan J, Craddock N, Jones IR, Goldman D, Heston LL, Sommer SS (2004) MECP2 structural and 3'-UTR variants in schizophrenia, autism and other psychiatric diseases: a possible association with autism. Am J Med Genet Part B (Neuropsychiatr Genet) 128:50-53

Tao J, Van Esch H, Hegedorn-Greiwr M, Hoffmann K, Moser B, Raynaud M, Sperner J, Fryns JP, Schwinger E, Gecz J, Ropers HH, Kalscheuer VM (2004) Mutations in the Xlinked cyclin-dependent kinase-like 5 (CDKL5/STK9) gene are associated with severe neurodevelopmental retardation. Am J Hum Genet 75:1149-1154

Van den Veyver IB, Zoghbi HY (2000) Methyl-CpG-binding protein 2 mutations in Rett syndrome. Curr Opin Genet Dev 10:275-279

Wan M, Lee SS, Zhang X, Houwink-Manville I, Song HR, Amir RE, Budden S, Naidu S, Pereira JL, Lo IF, Zoghbi HY, Schanen NC, Francke U (1999) Rett syndrome and beyond: recurrent spontaneous and familial MECP2 mutations at CpG hotspots. Am J Hum Genet 65:1520-1529

Weaving LS, Christodoulou J, Williamson SL, Friend KL, McKenzie OL, Archer H, Evans J, Clarke A, Pelka GJ, Tam PP, Watson C, Lahooti H, Ellaway CJ, Bennetts B, Leonard H, Gecz J (2004) Mutations of CDKL5 cause a severe neurodevelopmental disorder with infantile spasms and mental retardation. Am J Hum Genet 75:1079-1093

Young JI, Hong EP, Castle JC, Crespo-Barreto J, Bowman AB, Rose MF, Kang D, Richman R, Johnson JM, Berget S, Zoghbi HY (2004) Regulation of RNA splicing by the methylation-dependent transcriptional repressor methylCpG binding protein 2. Proc Natl Acad Sci USA 102:17551-17558

Zeev BB, Yaron Y, Schanen NC, Wolf H, Brandt N, Ginot N, Shomrat R, Orr-Urtreger A (2002) Rett syndrome: clinical manifestations in males with MECP2 mutations. J Child Neurol 17:20-24 